\title{
Policy coalitions and ambitious politicians: a case study of Philippine social policy reform
}

\author{
Yusuke Takagi*
}

National Graduate Institute for Policy Studies (GRIPS), Tokyo, Japan

\begin{abstract}
The Benigno "Noynoy" Aquino administration witnessed a series of social policy reforms such as Republic Act (RA) 10533 (K-12 Law) and RA 10354 (Reproductive Health Law). The political process of this reform is full of intellectual puzzles considering the conventional knowledge on Philippine politics, which is mainly shaped by the framework of weak state. Why was the administration able to carry out the reforms despite the strong opposition from vested interests sustaining the weak state? This paper argues that ambitious politicians, i.e., those who differ in policy positions and seek to challenge the existing power structure, can work with policy advocates both in public and private sectors and create policy coalitions which result into policy reform. By tracing the political process of forming the policy coalitions, this paper aims to reveal the dynamic aspect of Philippine politics which has been neglected because of the dominance of the weak state framework.
\end{abstract}

Keywords: policy reform; policy coalition; ambitious politician; K-12; reproductive health law; civil society; social policy

\section{Introduction}

The Philippine government led by President Benigno "Noynoy" Aquino (2010-2016) carried out a series of social reforms. ${ }^{1}$ The administration highlighted social policies rather than economic or industrial policies when it announced the "landmark legislation" to emphasize its achievements in the first three years in office. The government, for instance, claimed that it strengthened the excise tax on alcohol and tobacco products through the Sin Tax Reform Act (RA 10351, hereafter the Sin Tax Law) for the purpose of enhancing the universal health care system (Sidel 2014). ${ }^{2}$ It also carried out an educational reform to extend the basic education period from 10 years to 12 years through the Enhanced Basic Education Act (RA 10533, hereafter K-12 Law). ${ }^{3}$ Moreover, it even stated that "Congress - spurred by the marching orders of President Aquino - made history in enacting the Responsible Parenthood and Reproductive Health Act (RA 10354, hereafter RH Law). ${ }^{4}$

The claim of making history through social policy reform seems to be more than a usual self-admiration considering the controversies in the policy making process of each law. In fact,

\footnotetext{
*Email:y-takagi@grips.ac.jp
} 
one of the above-mentioned measures had been discussed for more than five decades, but opposed, taken the teeth out of regulations, or simply abandoned before the Noynoy Aquino administration. For instance, the powerful tobacco lobby had prevented the Gloria MacapagalArroyo administration (2001-2010) from fully enforcing the sin tax. Most of those who opposed the extension of basic education cycles were actually educational professionals who knew the financial difficulties of families to send their children because of hidden costs of "free" education. Meanwhile, in the case of reproductive health, we can find a series of clashes between the advocates and the highly organized Roman Catholic Church, whose political power is not negligible in the Philippines as we will see below.

Why was the Aquino administration able to achieve the series of policy reforms despite the weakness of the state? Who were the actual policymakers making the policy reform possible? Why did they take initiatives for the reform? How did they face the opposition?

This paper addresses these questions by examining the politics shaped by policy coalitions composed of ambitious politicians, professionals, nongovernment organizations (NGO) workers, and so on. ${ }^{5}$ As it will be explained more in the first section, this paper sheds a new light on the actions by politicians. Some of them just follow the logic of patronage politics and enjoy the benefits of being the allies of the president; others may differ in position on particular policy issues from the incumbent president or even challenge the existing vested interest structure of the weak state. This paper calls the politicians who take the latter type of the action ambitious politicians because they are more determined and energetic to make a difference. Some of them seek higher office such as the presidency, vice-presidency or the Senate, by projecting themselves as the politicians who are serious about the national agenda.

This paper argues that the policy coalitions sustained by the ambitious politicians can make a difference even in a situation where there is a weak state. The rest of the paper is composed of four sections and a conclusion. The first section explains the politics of policy coalition as a framework to understand the dynamics of Philippine politics. The second section studies the emergence of the policy coalition working for the reproductive health law. It traces the process of coalition making by changing the way to frame the issue, which enabled different groups of policy advocates to work together under the same umbrella. The third section studies the educational reform in which some members of private business took the initiative in cooperation with several professionals in the field of education. In both cases, we can find ambitious politicians who supported the reform at the risk of temporal political setbacks, which is the topic of the fourth section. The conclusion puts the findings in a broader context of Philippine politics.

\section{The politics of policy coalitions}

The politics of social policy reform is, in fact, an intellectual puzzle for those who are familiar with conventional knowledge of Philippine politics. This is because the Philippines has been 
assumed as a weak state where the government resources are exploited by political families, whose rent-seeking activities have often prevailed over public interests (Anderson 1988, Youngblood 1987, McCoy 1994). Those who study the winning coalition at the time of democratization highlight the conservative nature of the "dominant bloc" composed of the business elites, the Catholic Church, and the foreign forces such as the United States (U.S.) government sustaining the status quo (Hedman 2006a).

The analysis adopting the concept of the weak state has been reproduced in comparative studies of Southeast Asia. Kuhonata, for instance, classifies the Philippine state into the category of patrimonial state (Kuhonta 2008). In his comparative study of the Asian financial crises in 1997, Pepinsky also argues that the Philippine government avoided the crises because of its small amount of foreign capital due to its infamous rent-seeking activities (Pepinsky 2015). In a comparative study on welfare regimes in East Asia, Eastern Europe and Latin America, Haggard and Kaufman argue that the Philippines has been suffering from patronage politics, which has prevented the government from providing social welfare, and repeatedly characterize the Philippines as an exceptional case in East Asia (Haggard and Kaufman 2008, $32,66,188,191,261){ }^{6}$

As long as we accept these conventional literature on the Philippine state, however, we cannot understand the initiatives for the social policy reform by the Aquino administration. The administration secured the RH law despite strong opposition by the Catholic Church, or the part of the so-called dominant bloc. In terms of the K-12, the administration also went beyond the logic of the weak state dominated by oligarchs who have sought short-term interests for their own districts at the sacrifice of the public interests of the nation. How should we understand the politics of reform?

There are three different approaches in studying the dynamics of Philippine politics, which help us to understand the politics of policy coalitions. First, there are rich studies on civil society in the Philippines (e.g. Hedman 2006a; Quimpo 2008). Among them, Quimpo's argument of contested democracy fits most of our study. In his study on restored democracy after 1986, he highlights the role of the left movement in electoral politics. He traces the changing strategy of the left movement and highlights the split of the left in the early 1990s, which resulted into the emergence of social democrats (Rocamora 1994; Quimpo 2008; Tolosa 2011). His study encourages us to widen our eyesight to understand the dynamics of Philippine politics beyond the weak state. While his study focuses on democratic consolidation contested by the oligarchs and the left, this study unpacks the politics of policymaking shaped by policymakers who work for social policy reform.

Second, recent studies on economic policymaking provide us with a useful perspective to understand social policy reform (Raquiza 2012; Takagi 2016). Instead of viewing politics as structural constraints of policymaking, these studies suggest that political power struggle can be a thrust for policymaking. In the 1930s, for instance, then young but promising politicians 
worked for making a central bank in cooperation with professionals despite the opposition or neglect by the American colonial authority and established Filipino colonial politicians (Takagi 2016, ch. 2-3). In her comparative study on economic policymaking in Thailand and the Philippines, Raquiza argues that Filipino policymakers have prioritized political calculation over economic rationality (Raquiza 2012). She, for instance, highlights the facts that President Ferdinand Marcos (1965-1986) attacked economic interests of his political enemies such as the Lopezes through various economic policies, while the successive Corazon Aquino (1986-1992) and Fidel Ramos (1992-1998) administrations made use of decentralization as well as liberalization to dismantle the economic bases of Marcos cronies after 1986 (Raquiza 2012). A series of studies on technocracy in Southeast Asia also argues that we should study the political dimension of economic policymaking (Tadem, Khoo, and Shiraishi 2014). We can, therefore, expect some positive roles of particular politicians seeking for power even in the reform policy making.

Third, those who criticize the monolithic view of the weak state revisit the politics of the president. Abinales, for instance, mentions that the president is supported by coalitions which cannot be resolved into individual politicians seeking for interests in their own districts, but which are composed of different groups with their own agenda. The coalition politics might create pockets of efficacy in the midst of weak state capability (Abinales 2005; also cf. Evans 1995). In addition, Thompson specifies four main groups shaping the dynamics; these are civil society, the Church, big business and the military (Thompson 2014).

The remaining question in the literature on political coalition might be what the presidency exercises its muscle on. Even if the presidents attempt to use their power for their own political survival, they should choose whether they utilize the existing power structure through patronage or dismantle or at least unsettle it by policy reform. In one article, Thompson argues that there is a cycle in Philippine presidential politics, which is reform, populism, and patronage (Thompson 2010). As he aptly mentions, the mainstream presidential style after democratization is reform and good governance (i.e. no corruption) but at the same time, the style could be interrupted by different styles such as populism and patronage politics.

While the existing study on coalition politics has succeeded in highlighting pockets of efficacy under the power of the presidency (Abinales 2005), this study focuses more on the process of creating particular policy coalitions including the ambitious politicians. This is because the emergence of coalitions based on policy ideas are independent of the rhythm of presidential elections and institutional capability of the president, or the so-called "presidential bandwagon" (cf. Kasuya 2008). As we will see below, there are examples of the politicians who play an essential role in policymaking which is not necessarily supported by the incumbent presidents. These politicians are more ambitious than the politicians seeking only for a bigger share of their patronage. ${ }^{7}$ They are ambitious in the sense that they are determined in a particular policy issue and so aggressive to choose the opposing position against the president. 
They attempt to project themselves as new leaders by advocating new policy proposals which might change the vested interest structure (cf. Takagi 2016).

The policy coalition often involves advocates in the private sectors both in civil society and businesses because of the institutional nature of the Philippine state which makes the policymaking process porous to various actors. ${ }^{8}$ As most observers have pointed out, the 1987 Constitution in fact encourages members of civil society to work for the public goods through various institutional arrangements including the party-list system of representation, or a type of proportional representation, in the Lower House of Congress (Abinales 2005, 136; Faustino and Fabella 2014, 37-38). Moreover, there are several cases where presidential appointees begin to work in acting capacity but fail to be concurred by the bicameral Commission on Appointments of Congress, which resulted in increasing number of people who are appointed to the posts.

Besides, the constitution only allows a single term for the president who can appoint various high ranking officials in government, which eventually created a pool of professionals who know policymaking not only within but also outside of the government. Even under almost a decade-long Arroyo presidency (2001-2010), for instance, the president appointed cabinet members more than twice. Because of the expose of possible electoral fraud in the general election in 2004, high ranking officials including cabinet secretaries resigned from the Arroyo administration. Those who resigned are thereafter called the Hyatt 10, because they held a press conference at the Hyatt hotel to announce their resignation. Among the Hyatt 10, the succeeding Noynoy Aquino administration appointed Corazon "Dinky" Soliman, the Secretary of the Department of Social Welfare and Development, Florencio "Butch" Abad, the Secretary of the Department of Budget and Management, and so forth.

Combining the perspectives on the politics of contested democracy, economic policy making, and coalition politics, this study sheds a new light on the roles played by the policy coalitions. The coalitions are not necessarily formed or deformed by the president, though they depend on the power of the presidency to carry out the policy proposals. This paper hereafter traces the process in which policymakers either in civil society or government began their advocacy, and then form policy coalitions with several politicians who know policymaking but are not satisfied with the status quo.

\section{The policy coalition for the Reproductive Health Law}

The Responsible Parenthood and Reproductive Health Act, or the RH Law, is, in essence, an act to promote reproductive health through the distribution of contraceptive measures in family and sex education in schools. Before the passage of the RH Law, the women's rights movements have advocated the reproductive rights for decades, while some economists have supported family planning considering its possible contribution to economic growth (Danguilan 1997; Ocampo 2014, 119). The passage of the law was a milestone for the 
advocates.

The passage of the RH Law is, however, not an achievement but rather a setback for a leading Catholic organization in the country, the Catholic Bishops' Conference of the Philippines (CBCP). The CBCP opposed the RH bill by arguing that the bill gives people "a moral choice: to choose life or to choose death" (Odchimar 2011). The CBCP has opposed any form of contraception including "contraceptive mentality" for decades (Legaspi 1990). According to its "guiding principles," the Church is an authority for teaching responsible parenthood, with which parents should not avoid procreation and must raise children. According to their view, the contraceptive mentality is opposing the procreation, hence it is a culture of death (Bautista 2010). ${ }^{9}$ The church can promote natural family planning but does not allow its usage with the contraceptive mentality (Legaspi 1990).

The CBCP's opposition has serious political meaning in the Philippines, not only because more than 80 percent of its population are Roman Catholic but because the CBCP has actively engaged itself in politics since democratization in 1986 (Youngblood 1987). At the beginning of the downfall of the Marcos regime, the CBCP led by the charismatic Jaime Cardinal Sin declared its opposition to Marcos' regime and its support to the anti-Marcos struggle (Thompson 1996). Sin continuously supported Corazon Aquino, who took over the presidency, through personal consultation with her and by publishing pastoral letters on political issues such as elections, the Constitution, and so on (Youngblood 1987; Claudio 2013, 48-50). In the process of constitution making, in fact, the CBCP succeeded in sending at least one religious representative in two-thirds of the preparatory committees and in reflecting their interests in the 1987 Constitution such as a ban on abortion, religious instruction in public schools, and parental rights in educational and family planning decisions (Youngblood 1987, 1250). Because of the ban on abortion by the Constitution, in fact, health and medical professionals advocating contraceptives are accused as "anti-life" by the Church (Claudio 2013, $49,181)$.

The CBCP was fully aware of its influence on constitution making and made use of its past achievements in the midst of the controversy over the RH law. For instance, the CBCP said,

we [CBCP] begin [its pastoral letter] by citing the Philippine Constitution. We do so because we intend to write you on the basis of the fundamental ideals and aspirations of the Filipino people and not on the basis of specifically Catholic religious teachings," and reiterated that "we strongly reject the $R H$ bill [sic]. (Odchimar 2011)

The CBCP clearly opposed the bill not as a religious order but more as a political pressure group.

Considering the nature of the above-mentioned dominant bloc and vocal opposition by 
the CBCP against the RH bill, the strong support by President Aquino, none other than the son of former President Corazon Aquino, to the RH bill is a puzzle to be explained. Aquino won the presidential election mainly because of his mother's reputation and the memory of people power in 1986 (Thompson 2014).Corazon Aquino, a devout Catholic and a close friend of Cardinal Sin, was close to the position of the $\mathrm{CBCP}$ when it comes to reproductive rights. The CBCP remained active in politics and in fact succeeded in preventing the successive governments from making reproductive health measures (Ocampo 2014).

We now shift our focus from inside the government to outside, in order to find the origin of the RH law.

The concept of reproductive health is a focal point where various stakeholders including social movement activists, medical practitioners, and economists could jump into the issue. President Fidel Ramos was the first president who faced a confrontational Church on this issue because of his uncooperative relations with Cardinal Sin of the CBCP (Youngblood 1998). After Ramos, a non-Catholic, took over the presidency from Aquino in 1992, he announced Philippines 2000 as his administration's agenda for development (Ramos 1993). He pointed out that the Philippines had a $2.3 \%$ population growth rate, which was one of the highest in the region, and argued that his administration aimed at decreasing it to below $2 \%$ by the end of his presidency (Ramos 1993). ${ }^{10}$ To achieve this, President Ramos appointed a well-known medical doctor, Juan Flavier, as the health secretary despite opposition from Sin (Youngblood 1998, 12).

Flavier was often remembered as the doctor to the barrios because of his social engagement through the Philippine Rural Reform Movement (PRRM), one of the largest NGOs in the Philippines (Flavier 1970). He was born to a family of mechanics working at a mining site in Balatoc, Benguet in 1935 (InterAksyon 2014). After graduating from the College of Medicine, the University of the Philippines, he began working at the PRRM to promote health services in rural areas. The PRRM recruited young medical practitioners and sent them to the rural areas where the Huk rebels mobilized peasants into anti-government rebellion (Flavier 1970). After resigning as the health secretary, he ran for the Senate and eventually become the Senate President later. Because of the vocal promotion of the reproductive health, however, he became a victim of the frontal attack by the CBCP in the early 1990s.

An international conference served as a trigger to bring President Ramos and the CBCP into a collision course (Danguilan 1997). In September 1994, the United Nations Population Fund (UNFPA) took an initiative to introduce the idea of reproductive health at the International Conference on Population and Development held in Cairo, Egypt (Ocampo 2014, $121,125)$. With this concept, the UNFPA introduced a human rights-based approach to deal with the population problem (Oizumi 2007, 23-24). This new concept allowed two different groups to work together. While the old concept of population and family planning could be assumed hostile to women's rights due to its neglect of reproductive rights of women, 
reproductive health was assumed as a human rights-based approach and worked as a new concept with which advocates for family planning, gender equality, and human rights could work together (Ocampo 2014, 121-123).

The CBCP was not at all cooperative to the conference from the beginning. It published, for instance, its pastoral letter on the conference with its concerns about "deep and well-founded forebodings" (Morelos 1994). In the letter, CBCP explained that it had already communicated with President Ramos and revealed that " $[\mathrm{t}]$ he President already knows well the Catholic position against direct contraception, direct sterilization and direct abortion" (Morelos 1994). The CBCP actually succeeded in replacing the delegation head from health secretary Juan Flavier to National Economic Development Authority (NEDA) Director General Cieltito Habito (UCA News 1994). Flavier had been attacked by Catholic leaders for "his hard-sell approach in promoting the government's family planning program, which promotes liberal use of artificial contraceptives" (UCA News 1994).

Flavier ended up being a member of the delegation, and he was not the only medical doctor facing pressure from the Church. Drs. Macagba Tadiar and Marilen Danguilan, members of the delegation of the Philippines during the 3rd Preparatory Committee to the ICPD in New York in May 1994, were replaced by other delegates who were approved by the Church. The two doctors had worked hard for reproductive health for so long. After graduating from medical school, for instance, Danguilan faced the reality where patients often return to the clinic not simply because of disease but rather because of socio-economic conditions inducing various diseases. She was then determined to work in the Senate to make policies to promote public health. She closely worked with Senator Edgardo Angara and supported passage of laws on the generics medicine, health insurance, anti-smoking, and so on (Danguilan 2014; Dalisay 2015).

It took five more years, however, for policymakers to draft the first bill for reproductive health in 2001 (Ocampo 2014, 125-126). Facing stiff opposition from the CBCP as well as direct pressure from the Vatican, President Ramos did not step further on the issue of reproductive health during his term (Danguilan 1997, 42). Danguilan reported that Benjamin De Leon, the assistant secretary of social service for the president, often told her and other delegation members that they had to protect the president (Danguilan 1997, 62). In her study on the whole process of international relations on reproductive health published in 1997 , Danguilan stated that "the Church was - and has been - the most important and powerful political player in the country" (Danguilan 1997, 46) ${ }^{11}$.

The advocates deepened their network and widened their actions at every occasion in local, national and international levels. The health advocates had actually provided various community services including enhancement of reproductive health without laws since the 1960s (Flavier 1970, ch.10). They however faced opposition by several local government heads in the late 1990s (Claudio 2015a). For instance, Governor Joey Lina of Laguna Province suddenly banned artificial contraceptives from the public health center and clinics in the 
province (Rimban 1996). Lina was a senator from 1987 to 1992 and an active member of the Pro-Life movement (Rimban 1996). Following Governor Lina, Mayor Lito Atienza of Manila "banned" contraception in the capital city through his Executive Order (EO) no. 3 in 2000, which resulted in fatal consequences on the reproductive health in the capital city (Kebriaei 2007).

Against this backdrop, the advocates made use of another momentum at the International Conference on Population and Development plus 5 (ICPD plus 5) of the UNFPA in Beijing to review the implementation of the Cairo conference (Ocampo 2014, 125-126). In the conference, the Filipino delegates composed of Congresswoman Bellaflor Angara-Castillo, Dr. Junice Demetrio-Melgar, and others worked together. After the conference, they filed the first Reproductive Health bill at the $12^{\text {th }}$ Congress in 2001 (Ocampo 2014, 126).

Angara-Castillo is a longtime politician in the lower house and became a governor of Aurora province later. She was the House Majority Floor Leader from 1998 to 2001 and the Deputy Minority Floor Leader from 2001 to 2004 (de la Cruz and Domingo 2014, 71). She depended on her position on her close relations with then President Joseph Estrada whose defeated vice presidential candidate was her brother, Senator Edgardo Angara. In addition, Demetrio-Melgar and other delegates for the ICPD plus 5 organized the Reproductive Health Alliance Network (RHAN) when they filed the bill (Ocampo 2014, 128-129). RHAN is composed of 30 organizations and the largest coalition in civil society to promote the RH bill. Meanwhile, the Philippine NGO Council on Population, Health and Welfare Inc.(PNGOC) worked on networking all over the country (Ocampo 2014, 129).

Aside from these two consortiums of NGOs, there are two organizations linking them with politicians and the private businesses respectively. One is the Philippine Legislators' Committee on Population and Development (PLCPD), which was organized in 1989 to advocate population and human development such as reproductive health, public health, and gender equality (PLCPD website). ${ }^{12}$ Aside from the RH law, it worked for anti-violence against women and anti-human trafficking acts (Ocampo 2014, 127-128). The PLCPD played the role of combining legislators and advocates in civil society especially at the second reading of the RH bill (Ocampo 2014, 128). Meanwhile, the Forum for Family Planning and Development Inc., or the Forum, was organized in 2004 with political or business leaders such as former President Ramos and Washington Sycip of the SGV, the largest accounting firm in the country, as members. ${ }^{13}$ De Leon, who was the chair of the Philippine delegation to the Cairo conference, could bring Ramos to the Forum and induce support from the UNFPA (Ocampo 2014, 134).

The UNFPA also played an important role in financing the advocacy campaign for RH in the Philippines (Ocampo 2014, 129). The UNFPA Philippines actually provided \$2.3 million for a five-year advocacy and coalition building program from 2005 to 2010 (Ocampo 2014, 129-130). The UNFPA increased its financial support to the advocates from $\$ 2.3$ million during the Arroyo administration to $\$ 6.4$ million during the Benigno Aquino administration (Ocampo 
2014, 137). It is also worth mentioning that the financial assistance during the Arroyo administration became largest in the year 2009 when the advocates considered an electoral campaign in the coming year (Ocampo 2014, 137).

While NGOs, politicians, and business leaders began to mobilize their support for the RH bill, the CBCP also organized a new coalition called the Pro-Life Coalition in 2008 (Ocampo 2014, 130). With this coalition, the CBCP could maximize its hierarchical structure stretching all over the Philippines. The coalition was also supported by the Pro-Life Foundation having advocated anti-abortion since the 1970s in cooperation with the U.S.-based Human Life International (Ocampo 2014, 132). The coalition included the Bishops-Legislators Caucus of the Philippines (BLCP), a counter organization of PLCPD (Ocampo 2014, 132). One of the key opponents of the RH bill was a former Senator, Francisco Tatad, and his wife Fenny (Ocampo 2014, 140). They are known as members of the Opus Dei sect of the Catholic Church. Opus Dei was one of the conservative sects of the Roman Catholic Church and maintains a certain influence in policymaking because of its role at the time of democratization (Hedman 2006a). Tatad was powerful enough to stop consideration of the RH bill because he was the chair of the Committee on Rules and Means.

Meanwhile, in Congress, Congressman Edcel Lagman, one of the closest allies of then President Gloria Macapagal-Arroyo, filed House Bill No.5043 (Reproductive Health and Population Development) in 2008. Lagman seemed to take over the role of the RH advocate in Congress from Angara-Castillo who shifted her focus from the RH bill to the issue of violence against women and children, which resulted in the Anti-Violence Against Women and their Children Law in 2004 (de la Cruz and Domingo 2014).

Lagman, however, failed to induce Arroyo's support to the bill. Arroyo could not push through the RH bill, because she desperately needed support from the CBCP in the midst of the historically low support rate of the public, several coup attempts, and possible mobilization of another popular uprising similar to the ones in 1986 and 2001. The CBCP openly opposed the idea of a popular uprising, while the business leaders, who had once worked with the CBCP, aggressively asked for Arroyo's resignation in public (Hedman 2006b, 188). Instead of the RH bill, the Arroyo administration stated that natural family planning, which is acceptable to the CBCP, was the only reproductive health policy in 2002 and re-stated it in 2004 through the Department of Health administrative order no.125 and 134 respectively (Ocampo 2014, 141). The administration actually worked together with the CBCP and claimed that the so-called natural family planning is the only RH policy (Ocampo 2014, 141). In this context, Arroyo repeatedly instructed her allied legislators to tone down the advocacy for the RH bill. Meanwhile, the CBCP worked hard to convince legislators to oppose the RH bill during the 2010 election. The CBCP published a leaflet entitled, "Catechism on Family and Life for the 2010 elections" with which priests and bishops talked directly to politicians in their districts to support candidates opposing the RH bill (Ocampo 2014, 142). Some of the high-ranking priests 
even used the holy mass to proclaim their oppositions against the RH bill (Ocampo 2014, 142).

During the 2010 election, Benigno Aquino, then the presidential candidate of the Liberal Party, expressed his support to the RH bill at the risk of losing supports from the CBCP (Ocampo 2014, 135). After the election, President Aquino included the RH bill in the priority bills and mentioned it in his 2012 State of the Nation Address (Ocampo 2014. 135). Meanwhile, Congressman Lagman who remained in the minority as the Minority Floor Leader still worked for the RH bill. President Aquino took at least twice direct actions to support the bill in 2012 . On August 6, he held a lunch meeting with about 180 legislators at Malacañang Palace to stop further interpellation for the RH bill (Ocampo 2014, 135-136). On December 3, before the third or the final reading on the $\mathrm{RH}$ bill, President Aquino met Liberal Party legislators and convinced opponents within the party either to abstain or to be absent during the voting sessions (Ocampo 2014, 136). The bill was finally passed on December 12, 2012.

\section{The policy coalition for education reform}

In the case of education reform, it is difficult to figure out clear opponents, which does not reflect easiness of the reform. In fact, the advocacy for a 12-year basic education has a longer history of defeat than that for reproductive health. According to the Department of Education (DepEd), the Philippines witnessed nine proposals to extend the educational period for almost a century (DepEd 2010). All the proposals were, however, either directly opposed or neglected for various reasons. The 1930 proposal to restore the last grade at the primary school was, for instance, suspended and never implemented until the K-12 (DepEd 2010).

Most of those who opposed the extension were indeed supportive of improving the educational environment of their children. They differ however from the reform advocates in their priority. The opponents of the education year extension prioritize the way to fix existing problems such as the lack of school facilities, teachers, teaching materials, and so on. Besides, those who had difficulty in sending their children due to various reasons including costs for transportation or tuition fees in the case of private schools have opposed the extension of the education period. In a weak state, as other scholars have emphasized, politicians seek for tangible and short-time benefits for their own districts, while they neglect the national agenda. As we will see below, some politicians indeed call the reform anti-mass reform. The reform is another academic puzzle to be examined.

In search of reformers, we should study the failed attempt of the bridge program under the Arroyo administration. Then Education Secretary Edilberto de Jesus in cooperation with his undersecretary Juan Miguel Luz worked for this program to support students who would like to go to university but need to study further (DepEd 2003). Secretary de Jesus issued DepEd Order No. 8 s. 2003, or the academic focused-bridging program integrated into the nonformal education accreditation and equivalency system, in order to address the learning needs of those who plan to enter college (DepEd 2003). They recognized that almost half of public 
school students failed to meet the cut-off score of $30 \%$ at their high school readiness test (LeeBargo 2004). ${ }^{14}$ The department also paid attention to the result of the international tests such as 2003 TIMSS, Trends in International Mathematics and Science Study, seriously, because the Philippines ranked 34 out 38 countries (DepEd 2010, 3). They found that they needed to add one more year to help students to understand especially English, mathematics and science. In an interview, Luz told this writer that they tried to "smuggled in" an additional year through the bridge program (Luz 2015).

President Arroyo, however, opposed the DepEd Order No. 8 and compelled them to abandon the bridge program. Within a year, the Department of Education decided to make the bridge program optional. Secretary de Jesus did not hide his disappointment on this decision and said that they should find a way to improve the score of their children (Lee-Bargo 2004). Soon after, de Jesus resigned and the post was taken over by Florencio "Butch" Abad who also resigned in 2005 because of the exposure of possible electoral fraud of President Arroyo in 2004. Luz finally resigned from the post in 2006 after continuing political turmoil created by the scandal and an excessive pressure from the Palace to fund a program of Arroyo's close ally in Congress (Araneta 2005; Lorenzo 2008). ${ }^{15}$ Luz then played an important role to organize a broader network for reform as we will see below.

Some business leaders organized an association to advocate education policy reform, especially the extension of the education cycle to 12 years. Ramon del Rosario Jr. organized the Philippine Business for Education (PBED) in 2006 (Torres 2006). The PBED's board of trustees is composed of business leaders such as Jose Cuisia, Jr. who is the former Central Bank governor and the president of the Philippine American Life and General Insurance, Oscar Lopez, Manuel Pangilinan, Washington Sycip and Jaime A. Zobel de Ayala II, in addition to Del Rosario. ${ }^{16}$ These names are familiar with the people who know the "business activism" in the people power revolution in 1986 (Hedman 2006a). Ramon V. del Rosario, father of Ramon del Rosario of the PBED, for instance, worked hard to support the electoral watch movement, National Citizens' Movement for Free Elections (NAMFREL), in the 1950s (Hedman 2006a, 54-55). Washington Sycip, a founder of the country's top accounting firm, SGV, has been active in the social engagements of the private business and worked for organizing the Philippine Business for Social Progress in the 1960s (Hedman 2006a, 100-102). Ramon himself was one of the prime movers of the Makati Business Club, an organization of Manila-based business leaders to oppose crony capitalism under the Marcos regime (Hedman 2006a: 104, also c.f. Mikamo 2013). Luz's brother, Guillermo Luz, was the executive secretary of the Makati Business Club and actively asked for the resignation of President Arroyo in 2005 (Araneta 2005).

Politicians opposing the Arroyo administration gradually realized the issue and indeed prepared the bill. Then Senator and opposition Liberal Party (LP) President Mar Roxas submitted Senate Bill No. 2294 (Omnibus Education Reform Act of 2008). ${ }^{17}$ In his explanatory 
note to the bill, Roxas advocated that the government should extend its basic education to 12 years and also provide universal and compulsory one year pre-school (Roxas 2008). Roxas' bill was, however, pending in the Committee on Education, Arts and Culture after the first reading.

Meanwhile, President Arroyo had organized the Presidential Task Force for Education chaired by Fr. Bienvenido F. Nebres, the president of the Ateneo de Manila University, in September 2007. The Task Force was assigned to review the existing education system and to make various recommendation to the president (Nebres 2010). In its terminal report published in May 2010, Chairman Nebres pointed out high dropout rates and low performance in basic education as well as mismatching in the job market for college graduates (Nebres 2010, 3). He actually mentioned that the 10-year basic education can be a part of the problems but did not elaborate on any policy proposal on this issue (Nebres 2010, 19). Instead, the Task Force recommended further institutional reform to strengthen cooperation mechanism among three education agencies, to enhance functions of the local education boards at the local government level, and to encourage the education sector to work more closely with the business sector to increase job opportunity (Nebres 2010). ${ }^{18}$ The proposal must sound well for the politicians who are seeking for funds to build schools or to increase teaching materials in their own districts. The reform advocates had to wait for the election in 2010and the establishment of a new administration.

In the midst of the electoral campaign, Benigno Aquino announced his educational reform agenda at the meeting of the $3^{\text {rd }}$ National Congress of the Coordinating Council for Private Educational Associations of the Philippines on February 11, 2010. Aquino, who had supported the above-mentioned Roxas' bill as an LP member, claimed that he would extend basic education once he won the election. It is interesting to remember that both Aquino and Roxas were not well-known as politicians who are keen to promote education reforms. For instance, Roxas established his career as an investment banker as well as secretary of trade and industry, while Aquino's political asset was more or less limited to the fact that he was the son of the icons of Philippine democracy, Benigno and Corazon Aquino. It is therefore important to know what the policy coalitions led by the PBED did.

A few months after the election, Luz revealed the members of the education reform team of the LP in public (Luz 2010, 12). The team was composed of former education secretaries Ed de Jesus, Butch Abad, Fe Hidalgo and Erlina Pefianco as well as former education undersecretaries, Chito Gascon and Luz himself. The board members of the PBED loudly supported Aquino's agenda for educational policy reform. Sycip said, "Definitely, I am in favor of pushing for a 12-year basic education because our college graduates are below par with the rest of the world" in his interview with a business daily (Reyes 2010, 5). Echoing Sycip's view, del Rosario argued that Philippine education should be "at par with global standards" (Reyes 2010, 5). He argued that the K-12 was a key agenda to improve the quality 
of education.

Meanwhile, in Congress, Senator Edgardo Angara, then the chair of the committee on education, supported the 12-year education cycle. He argues that, "[i]n education, the most fundamental proposal is the additional two years in our basic education curriculum" (Angara 2010, 11). Angara was once called "Senate's Mr. Education", because of his interest in education (Joaquin 2006). He was a lawyer by profession but was appointed the president of the University of the Philippines in 1981 before running for the Senate in 1987. He established his political career especially in the field of education and health and rose to the Office of the Senate President from 1993 to 1995 (Joaquin 2006; also, cf. Danguilan 2014).

There seems to be no strong counter-argument from the opposition. Majority Floor Leader, Senator Vicente Sotto, for instance, accused big business of advocating "anti-poor" reform (Purificacion 2010, 14). He argued that the reform would be an additional burden on poor families who had difficulty in sending their children because of various costs of education (Purificacion 2010, 14). Another Senator, Antonio Trillanes, questioned the impact of the K12 on the quality of education and asserted that the government address the issues of the lack of teachers and classrooms first (Salita 2010, 6). These arguments remind us of the recommendation of Arroyo's task force headed by Nebres. Nebres, in fact, opposed the reform plan saying that the governments hould fix the existing problems such as lack of educational facilities first. Otherwise, the additional two more years might end up with an additional number of students who cannot complete their study (Tiangco 2010, 5).

In the midst of the heated debate, the above-mentioned PBED and the Department of Education signed a memorandum of agreement not only to reiterate the PBED's commitment to support the K-12 but to express their commitment to hiring the graduates of K-12 (Ronda $2010,13)$. There can be found more direct linkage between the policy advocates and interests of business practitioners in the business process outsourcing industry. The business process outsourcing industry is the beneficiary of the reform. Alfredo Ayala, the president of the Business Processing Association of the Philippines (BPAP), admitted that the industry will get benefits from the reform (Hernando-Malipot 2010, 3). The BPAP is in fact one of the organizations to sign the MoA with the Department of Education. As Raquiza has revealed, several business elites have heavily invested in education as well as business process outsourcing business (Raquiza 2014; 2015). A support from the BPAP reflected the changing dynamics of the Philippine political economy, which is now led by the service sector spearheaded by business process outsourcing (Raquiza 2015).

On May 15, 2013, President Aquino signed the bill into law and the government finally carried out the longtime agenda for education reform. It is important to recognize the fact that the Aquino administration carried out the reform which had been discussed more than a half century, although the opposition failed to develop a convincing counterargument. Without the support from the private business, the administration would not have worked for the reform. It 
seems too much, however, if we claim that the business leaders were the sole reform agents in the story of educational reform. The following fourth section addresses the remaining question why these reforms were possible under the Benigno Aquino administration.

\section{Revisiting the Benigno Aquino administration}

One of the remaining questions is the timing of the reform. Why was the Aquino administration able to carry out the reform, while the Arroyo administration failed to complete or neglect the issue at the beginning? One simple answer to this is the high support rate President Aquino enjoyed. The following tables clearly show the popularity of President Aquino compared with that of President Arroyo. President Noynoy Aquino was popular mainly because of his family background. Noynoy is the only son of the late senator and the icon of Philippine democracy, Benigno "Ninoy" Aquino Jr. Noynoy was suddenly on the spot after the death of former President Corazon Aquino, who herself is another icon of Philippine democracy.

Considering the fact that Arroyo desperately sought for support from the Church and could not take any bold actions to carry out the reproductive health issue, it sounds convincing that the high support rate at least helps President Aquino to take a political risk.

This assertion does not sound convincing, however, once we look back at the support rates of other presidents in Figure 1. Both Cory Aquino and Fidel Ramos enjoyed a certain amount of the support bud did not push through the reform, though they knew the issues. What is the difference between President Benigno Aquino and his predecessors? We now turn to the supporting rate of not the president but the administration in Figure 2.

Figure 1. Net satisfaction ratings of the Presidents 


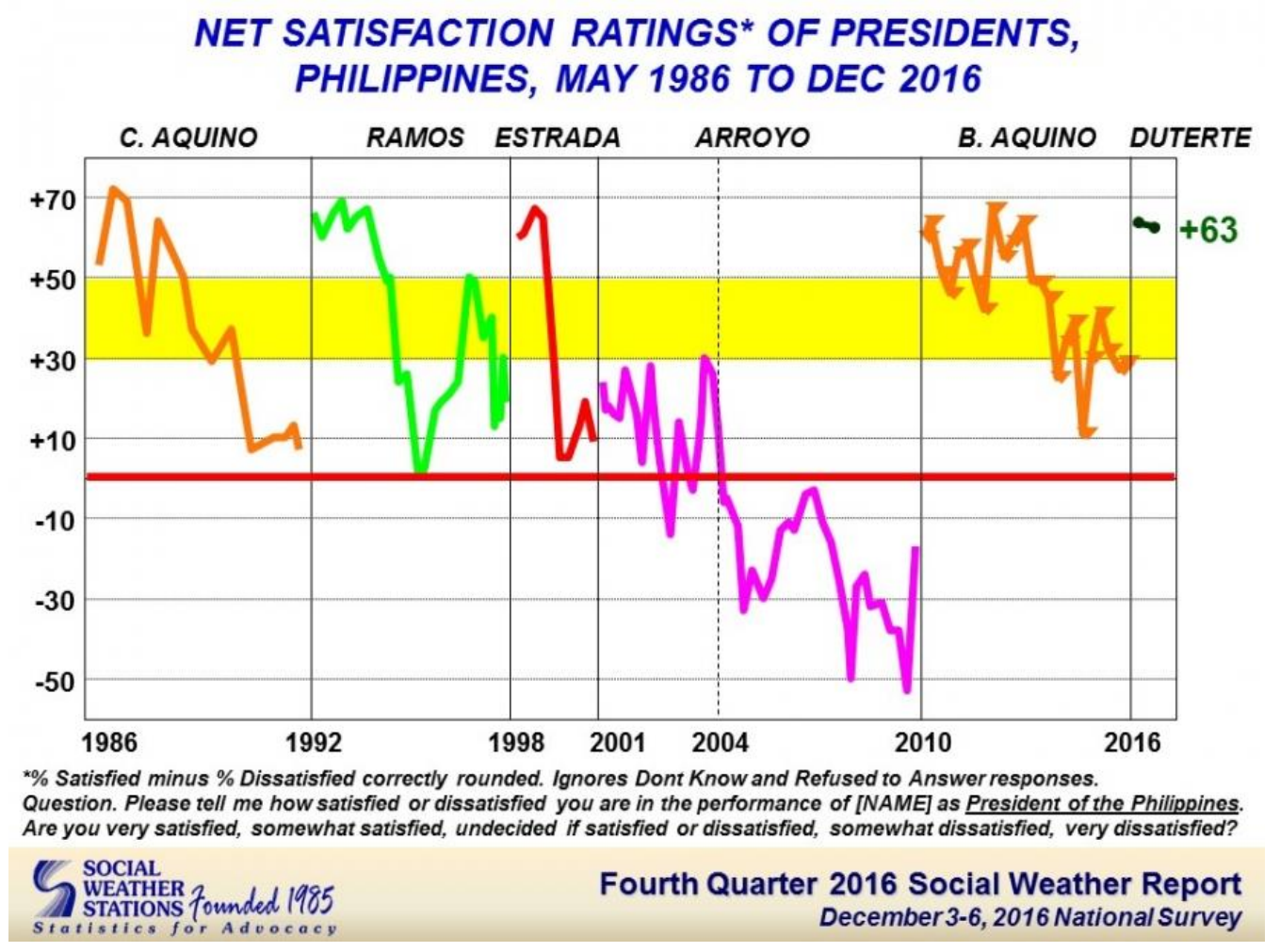

Source: Social WeatherStations, http://www.sws.org.ph/swsmain/artcldisppage/?artcsyscode=ART-20161215093954 accessed on January 8, 2017.

Figure2.Net satisfaction with general performance of the national administration
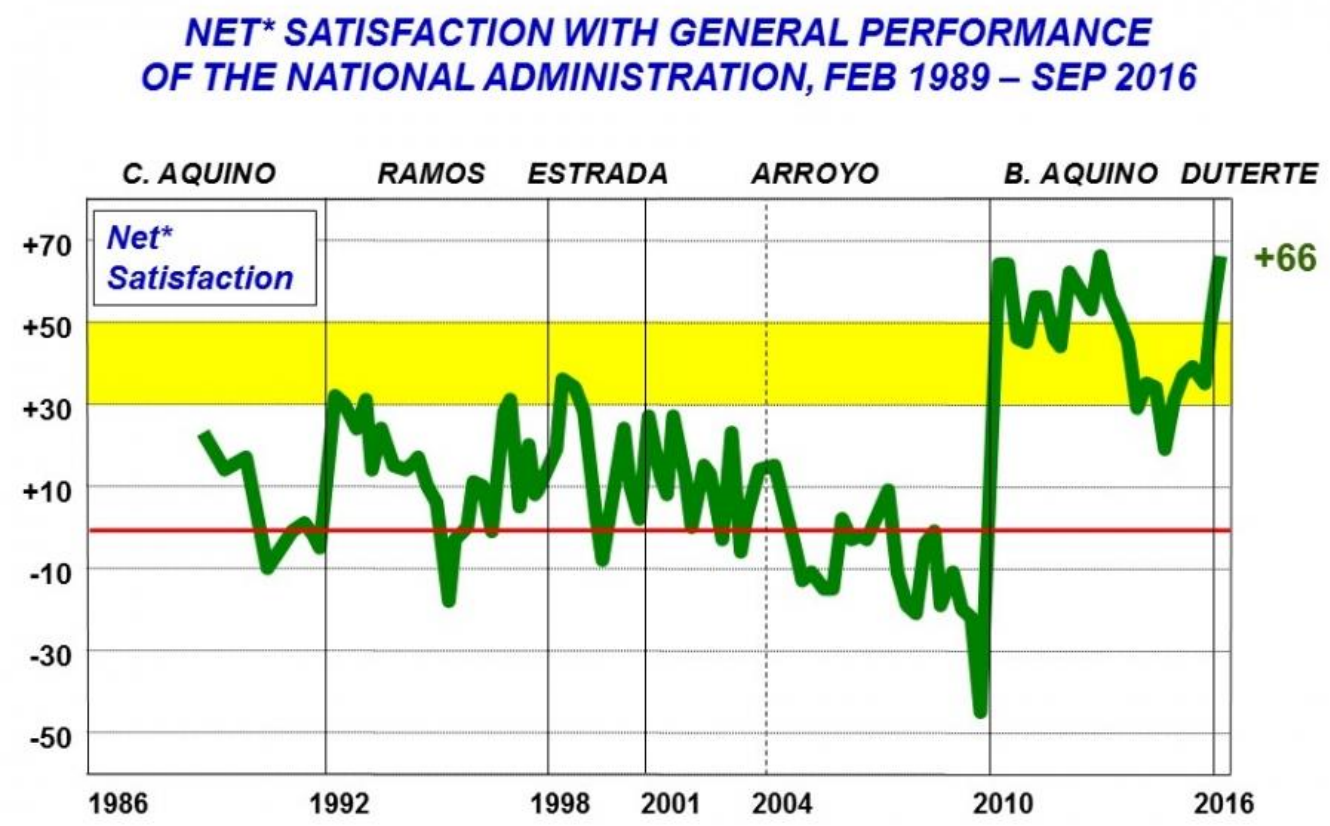

${ }^{*}$ Net figures (\% Satisfied minus \% Dissatisfied) correctly rounded.

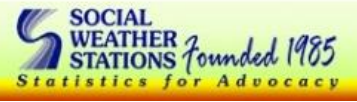

Third Quarter 2016 Social Weather Report September 24-27, 2016 National Survey

Source: Social Weather Stations,http://www.sws.org.ph/swsmain/artcldisppage/?artcsyscode=ART-20161117111243accessed on January 8, 2017 
Figure2 clearly reveals a remarkable supporting rate for the Noynoy Aquino administration compared with other administrations. The Filipino people distinguish their opinion on the president from that of the administration. We should look at what the administration has done.

Figure 2 reveals the record-low support rate of the Arroyo administration. It is quite puzzling, if we only consider economic performance as an indicator to explain the satisfaction with the administration's performance, as Thompson puts it (Thompson 2014). The Arroyo administration left a relatively healthy macroeconomic performance but ended up with such a low support rate. We should understand a political logic with which the Aquino administration picked up social policy rather than economic policy as landmark legislations. There are voices that demand social welfare aside from the healthy macroeconomic management. We now turn to the analysis of the policy coalitions in a longer time frame going beyond a single administration.

First of all, there is a gradual change in civil society. The Philippines witnessed a resurgence of the social democrats from the 1990s. As this writer has briefly mentioned in earlier sections, there is a group of policymakers who split from the Communist Party and began to work closely with the social democrats (Quimpo 2008). According to their memoir (Tolosa 2011), they organized themselves from the 1960s in response to the deteriorating credibility of the established political parties and increasing number of radical student movements because of the influence of the Chinese Cultural Revolution. ${ }^{19}$ After democratization, the Communist Party lost its popular support mainly because of its decision not to join the election in 1984, while the people who had worked as social democrats gained their momentum in the restored democratic government of President Corazon Aquino. Although they failed to consolidate their influence within the administration, they learned how to manage the administration (Tolosa 2011). There are several key players within the Noynoy Aquino administration who came from this tradition. Among others, Butch Abad, former education secretary, has played a key role in the Noynoy administration as the budget secretary. In the House of Representatives, party-list Representative Risa Hontiveros, who had risen from the tradition of the social democratic movement, maximized her close relations with President Aquino in the policy making process of the reproductive health law (Claudio 2015a).

In addition to a change in the traditional left, the civil society movements accumulated their experience in law making. NGOs such as Likhaan worked for reproductive health at the local level without a national RH law but faced opposition from local politicians including the mayor of the capital city. Sylvia Claudio, one of the co-founders of Likhaan, told this writer that they therefore decided to push for a law to establish a legal ground for their activities (Claudio 2015a). Another development in the civil society movement should not be underestimated, because the activists have gradually learned to participate in elections and public administration. The active members of a small but coherent party, Akbayan, played 
certain roles in the Noynoy administration. Quimpo's work on the transformation of the left movement can be read as a study on the learning process by the social movement activists who once took a militant and confrontational strategy and then gradually changed its strategy to win elections and even to manage public administration. However, the Akbayan party faced a challenge of leadership, when Walden Bello, a leading figure of the party and representative in Congress, resigned from Congress as a result of differences with the Aquino administration. Facing Bello's criticism, Claudio as a member of the party's Executive Committee introduced the argument of Richard Rorty saying:

the biggest gains were achieved not by people who measured their actions against some future vision of socialist utopias but by pragmatic considerations of what was merely better than what existed (Claudio 2015b).

Throughout their experience working as a coalition partner of the president, this section of the left movement transformed their politics.

In addition, there are politicians who are well aware of social policy. Throughout the study on social policy reform, this writer has often bumped into the name of the Angaras. Dr. Danguilan worked at Angara's office in drafting various laws for public health (Danguilan 2014). Senator Angara is the brother of Bella Angara-Castillo and also worked closely with Edcel Lagman, both of whom worked hard for the RH law. Although Angara failed to win the vice-presidential election in 1998, he continued to serve as a powerful senator until his retirement in 2013 (Dalisay 2015). In a political system where the Senate has often been assumed a training ground for future presidents, Angara's success in the Senate is worth mentioning. Although Angara was neither a member of the Liberal Party nor Akbayan, he supported the administration's education agenda as a leading member of the majority coalition in the Senate. In one sense, the career of the Angaras represents the career of politicians who emerged from the strand of the middle force of people power in 1986.

Lagman, whose brother was killed by militant communists because of his leadership of a split faction, was a lawyer but worked both at the government and a private law firm before he himself joined the anti-Marcos struggle as a human rights lawyer (Teehankee 2012, 63). After democratization, he won the election and worked for agrarian reform, government's debt management, and education while maintaining close relations with Senator Angara (Teehankee 2012, 64-65). He was ambitious enough to run for the Senate though he failed. While he was one of the most loyal supporters of President Arroyo, he worked hard to pass the RH bill at the sacrifice of the chairmanship of the Committee on Appropriation in Congress.

These politicians were not so straightforward in their ideological position. In fact, Senator Edgardo Angara was taken over by his son. Angara-Castillo became governor of Aurora province after her term was over and won another term in the Lower House in 2013, 
while Lagman's seat was taken over by his son, Edcel Lagman, Jr. One can criticize these politicians that they have become a part of political dynasties after 1986, dominating the seats with their own family members (cf. Teehankee 2012). We don't need to underestimate, however, the fact that they can work with reform advocates as we have seen in this study.

\section{Conclusion}

The politics of social policymaking reveals the dynamic aspect of the politics of policy coalitions. First, the policy coalitions reflect transformations of civil society. In addition to the NGO workers in the field, there are NGOs working for policymaking such as the PLCPD or PBED. These NGOs are supported by professionals, including medical practitioners or business leaders. Some medical practitioners had offered necessary social services in the field of RH but faced with opposition from local governments, which triggered their policy advocacy at the national level involving several politicians. Moreover, they broadened the coalition by reframing the issue not only as women's rights but as reproductive health, which allowed women's activists, economists, and medical practitioners to work together. In the case of K-12, the coalition is heavily supported by private business leaders who do not necessarily share the purpose of the reform with education specialists. The contested political process is not always dominated by the oligarchs and the left.

Second, some politicians cooperated with the reform advocates and worked together with the former. In both cases of the RH law and K-12, we can hardly neglect the roles played by the Angaras and those who closely worked with them such as Edcel Lagman. They could be assumed as being a part of a political dynasty using the network of their family but could work for a reform agenda. They are different from those who only follow the logic of the presidential bandwagon. It is interesting to remember that Congressman Lagman was often categorized as one of then President Arroyo's loyal allies in Congress when he advocated the RH bill which Arroyo had never supported. Politicians do not necessarily follow the orientation of the president despite the latter's power to control patronage.

Third, the presidents might oppose or support the policy agenda but does not dominate the entire process of policymaking. President Benigno Aquino indeed played an important role in policy making in the final phase but he was not the one to take the initiative at the beginning of the actual law making. The reform advocates had worked before the inauguration of the Aquino administration. The politics of the policy coalitions is therefore not dominated by the president but is open to the policy advocates who can make broad coalitions in civil society, Congress and the presidential palace.

In addition, a porous nature of the policymaking encourages various actors to play the role in policymaking. Some of them are professionals who have once worked at the government as presidential appointees but also worked in private sectors based on their own profession. They do not stop working for the public interest even after their departure from the 
administration. In the field of public health, medical doctors worked for reform in cooperation with various NGOs and business leaders, while in the education sector, the business leaders concerning about the quality of graduate have worked for reform. The brief sketch of the politics of policy reform reveals the existence of policy coalition which is not limited to the government and worked for policy reform.

\section{Acknowledgements}

This is one of the products of the Emerging State Project under the Grant-in-Aid research projects No. 25101004 and the Leading Initiative for Excellent Young Researchers of the Japanese government. The writer gratefully acknowledges comments and suggestions on earlier drafts by Lisandro Claudio, Veerayooth Kanchoochat, Fumiharu Mieno, Yoichiro Mine, Masayuki Tanimoto, and Keiichi Tsunekawa as well as key interviewees such as Marilen Danguilan, Juan Miguel Luz, and Sylvia Claudio Estrada. Among them, the writer is very much grateful for Dr. Danguilan who has provided vital help since the very early stage of this research. The writer is also grateful for detailed comments from two anonymous reviewers; they, of course, bear no responsibility for any error in this research.

\section{About the contributor}

Yusuke Takagi, Doctor of the Science of Law (SJD), is Assistant Professor, National Graduate Institute for Policy Studies (GRIPS), Tokyo, Japan. His doctoral dissertation is recently published as, Central Banking as State Building: Policymakers and Their Nationalism in the Philippines, 1933-1964. (Quezon City: Ateneo de Manila University, Singapore: National University of Singapore Press and Kyoto: Kyoto University Press, 2016).

\section{References}

Abinales, Patricio. N. 2005. Governing the Philippines in the Early 21st Century. In After the Crisis: Hegemony, Technocracy and Governance in Southeast Asia, edited byShiraishi Takashi and Patricio N. Abinales, 134-155. Kyoto: Kyoto University Press.

Anderson, Benedict. R. O’G. 1988. "Cacique Democracy in the Philippines: Origins and Dreams."New Left Review 169: 3-31.

Angara, Edgardo J. 2010. "More Critical than Ever.” Manila Bulletin, August 15: 11.

Araneta, S. 2005. “Sacked DepEd Exec Won't Leave Government."Philippine Star, September 2 http://www.philstar.com/headlines/298768/sacked-deped-exec-won\%C2\%92t-leavegovernment

Bautista, Julius. 2010. "Church and State in the Philippines: Tracking Life Issues in a 'Culture of Death"” Sojourn: Journal of Social Issues in Southeast Asia. 25 (1): 29-53.

Claudio, Lisandro E. 2013. Taming People's Power: The EDSA Revolutions and their Contradictions. Quezon City: ADMU Press. 
Claudio, Sylvia Estrada. 2015a. Personal Interview, Quezon City, Metro Manila. Sept. 23.

Claudio, Sylvia Estrada. 2015b. "The conscience of another progressive: Why I stay on with Akbayan" Rappler, Nov. 9. http://www.rappler.com/thought-leaders/112151-conscienceprogressive-staying-akbayan

Dalisay, Jose Y. 2015. Edgardo J. Angara: In the grand manner. Quezon City: University of the Philippines Press.

Danguilan, Marilen J. 1997. Women in brackets: A chronicle of Vatican power and control. Pasig City: Philippine Center for Investigative Journalism.

Danguilan, Marilen.2014. Personal interview, Makati City, Metro Manila. August 16.

De Jesus, Edilberto.2010. “Education Reform.” Business World, September3: 4-5.

de la Cruz, Abigail. R. and Michelle. H. Domingo. 2014. "The Passage of the Law to Address Violence against Women in the Philippines." In Room for Maneuver: Social Sector Reform in the Philippines, edited byR. Fabella, J. Faustino, A. Leftwich, and A. Parker, 57-91. Makati City: The Asian Foundation.

DepEd [Department of Education]. 2003. "Academic focused-bridging program integrated in the no formal education accreditation and equivalency system" DepEd Order No. 8, s. 2003, Feb. 12.

2010. "Discussion Paper on The Enhanced K+12 Basic Education Program," DepEd Discussion Paper, 05 October.

Evans, Peter. 1995. Embedded Autonomy: States and Industrial Transformation. Princeton: Princeton University Press.

Faustino, Jaime. and Raul. Fabella. 2014. "The Philippine Cont ext for Social Reform." In Room for Maneuver: Social Sector Reform in the Philippines. Eds. Fabella, Raul, Jaime. Faustino, Adrian. Leftwich, and Andrew. Parker, 29-55. Makati City: The Asian Foundation.

Flavier, Juan M. 1970. Doctor to the Barrios, Experiences with the Philippine Rural Reconstruction Movement. Manila: New Day Publishers.

Haggard, Stephan and Robert. R. Kaufman. 2008. Development, Democracy, and Welfare States: Latin America, East Asia, and Eastern Europe. Princeton: Princeton University Press.

Hedman, Eva-Lotta E. 2006a. In the Name of Civil Society: From Free Election Movements to People Power in the Philippines. Quezon City: ADMU Press.

Hedma, Eva-Lotta E. 2006b. "The Philippines in 2005: Old Dynamics, New Conjuncture." Asian Survey, 46 (1): 187-193.

Hernando-Malipot, I. 2010. “DepEd's K + 12 PlanSeen to Boost BPO.” Manila Bulletin, Nov. $4: 3$.

InterAksyon. 2014. Juan Flavier - Mr. Let's DOH It, People's Senator - quietly passes away. (http://www.interaksyon.com/article/98237/juan-flavier---mr--lets-doh-it-peoples-senator--quietly-passes-away, accessed Oct. 30, 2014))

Kasuya, Yuko2008. Presidential Bandwagon: Parties and Party Systems in the Philippines. 
Tokyo: Keio University Press.

Katzenstein, Peter. J. 2005. A World of Regions: Asia and Europe in the American Imperium. Ithaca: Cornell University Press.

Kebriaei, Pardiss. (ed.) 2007. Imposing Misery: The Impact of Manila's Ban on Contraception. Quezon City: Kikhaan, Manila: ReproCen, and New York: Center for Reproductive Rights. Kuhonta, ErikM. 2008. "Studying States in Southeast Asia." In Southeast Asia in Political Science, Eds. E. M. Kuhonta, D. Slater, and T. Vu, 30-54. Stanford: Stanford University Press.

Legaspi, Leonardo Z. 1990. "Guiding Principles of the Catholic Bishop's Conference of the Philippines on population control." http://cbcpwebsite.com/1990s/1990/guidingprinciple.html

Lee-Brago,P. 2004. DepEd bridge program now optional. Philippine Star. June 9, 2004 http://www.philstar.com/headlines/253149/deped-bridge-program-now-optional.

Lorenzo, I. 2008. "Politics causes civil service to lose a few good men and women." Philippine Star, April 27. http://www.philstar.com/headlines/58508/politics-causes-civil-servicelose-\%E2\%80\%98-few-good-men-and-women\%E2\%80\%99.

Luz, Juan Miguel. 2015. Personal Interview, Makati City, Metro Manila. Sept. 26.

McCoy, Alfred(ed.)1994. An Anarchy of Families: State and Society in the Philippines. Quezon City: Ateneo de Manila University Press.

Mikamo, Shingo. 2013. "Business Associations and Politics in the post-EDSA Philippines: Neither Oligarchy nor Civil Society."Philippine Political Science Journal34 (1): 6-26.

Morelos, Carmelo. D. F. 1994. "Pastoral Statement on the Cairo International Conference on Population and Development." Catholic Bishops' Conference of the Philippines. http://cbcpwebsite.com/1990s/1994/cairo.html

Nebres, Bienvenido F. 2010. The Philippine Main Education Highway: Terminal Report of the Presidential Task Force for Education to the President and the Cabinet. Manila: Malacanang Palace.

Ocampo, Jamir. N. P. 2014. "Structure and Agency in Contentious Reform: Reproductive Health Policy in the Philippines." In Room for Maneuver: Social Sector Reform in the Philippines, edited by RaulFabella, Jaime Faustino, Adrian Leftwich, and Andrew Parker, 119-150. Makati City: The Asian Foundation.

Odchimar, Nereo. P. 2011. "Choosing Life, Rejecting the RH bill." Pastoral Letter of the Catholic Bishops' Conference of the Philippines. http://cbcpwebsite.com/2010s/2011/choosing.html

Oizumi, Keiichiro. (大泉啓一郎). 2007. Oiteyuku Ajia: Han'ei no Kozu ga Kawaru Toki (老い てゆくアジア一繁栄の構図が変わるとき, Aging Asia: When the Prosperous Picture Changes). Tokyo: Chuokoron-Shinsha, Inc.

Philippine Statistical Authority. 2010. Census of Population and Housing. 
https://psa.gov.ph/statistics/census/population-and-housing.

Pepinsky, Thomas. B. 2015. "Political Business and External Vulnerability in Southeast Asia." In Two Crises: Different Outcomes; East Asia and Global Finance. Eds. T. J. Pempel and Keiichi Tsunekawa,137-162. Ithaca: Cornell University Press.

Purificacion, M. 2010. "Sotto Slam Business over K + 12 Education Program.” People's Tonight. October 8: 14.

Quimpo, Nathan Gilbert. 2008. Contested Democracy and the Left in the Philippines after Marcos. Monograph 58/ Yale Southeast Asia Studies. New Heaven: Yale University Press.

Rimban, L. 1996."Laguna bans condoms, other contraceptives in public clinics" Manila Standard, June. $9, \quad$ p. $\quad 6 . \quad$ Google News https://news.google.com/newspapers?nid=1370\&dat=19960609\&id=eqEVAAAAIBAJ \&sji d=WgsEAAAAIBAJ\&pg=6478,1289235\&hl=ja

Ramos, Fidel V. 1993. "Second State of the Nation Address." Delivered at the Batasang Pambansa, Quezon City, July 26, 1993. (http://www.gov.ph/1993/07/26/fidel-v-ramossecond-state-of-the-nation-address-july-26-1993/, accessed on April 25, 2015).

Raquiza, Antoinette R. 2012. State Structure, Policy Formation, and Economic Development in Southeast Asia. New York: Routledge.

-2014. "Changing configuration of Philippine capitalism" Philippine Political Science Journal. 35(2): 225-250.

-2015. "Philippine service sector, politics and governance issue" Working paper for the Emerging States Project Workshop "Beyond crises and traps in Southeast Asia: Reshaping economic strategies, social policies and political configurations" National Graduate Institute for Policy Studies (GRIPS), May 15 -16, 2015

Reyes, R. R. 2010. “Top Execs Still Pushing for 12-year Education.” Business Mirror, August 15: 5 .

Rocamora, Joel.1994. Breaking Through: The Struggle within the Communist Party of the Philippines. Pasig City: Anvil Publishing Co.

Ronda, R. A. 2010. "PBED throws Support behind K + 12 Plan." Philippine Star, Oct. 21: 13. Salita, R. T. 2010. “Trillanes Finds K+ 12 Questionable.”Manila Standard Today June 10: 6. Sidel, John. 2014. "Achieving Reforms in Oligarchical Democracies: The Role of Leaderships and Coalitions in the Philippines.” Research Paper 27 Developmental Leadership Program, University of Birmingham.

Tadem, Teresa. S. Encarnacion., Khoo Boo Teik, and Shiraishi Takashi. eds. 2014. "Special Issue: The Politics of Technocracy in Southeast Asia." Southeast Asian Studies 3(2): 241438.

Takagi, Yusuke. 2016. Central Banking as State Building: Policymakers and Their Nationalism in the Philippines, 1933-1964. Quezon City: Ateneo de Manila University, Singapore: National University of Singapore Press and Kyoto: Kyoto University Press. 
Teehankee, Julio C. 2012. "Emerging Dynasties in the Post-Marcos House of Representatives." Philippine Political Science Journal. 22 (45): 55-78.

Thompson, Mark R. 1996. The Anti-Marcos Struggle: Personalistic Rule and Democratic Transition in the Philippines. Quezon City: New Day Publishers.

Thompson, Mark R. 2010. “After populism: Winning the 'war' for bourgeois democracy in the Philippines" In The politics of change in the Philippines, edited by Yuko Kasuya and Nathan G. Quimpo, 21-46, Pasig City: Anvil.

Thompson, Mark R. 2014. "The politics Philippine presidents make." Critical Asian Studies. 46(3), 433-460.

Tiangco, J. C. 2010. “LES LunchesDrive vs K + 12.” People’s Tonight. October 7: 5.

Torres, T. P. 2006. “Top Business Execs Lend Hand in Flaws in RP Education.” Philippine Star, August 25 http://www.philstar.com/business/354557/top-business-execs-lend-handflaws-rp-education

Tolosa, Benjamin T. ed. 2011. Socdem: Filipino Social Democracy in a Time of Turmoil and Transition, 1965-1995. Manila: Friedrich Ebert Stiftung.

UCA News. 1994. "Changes in Cairo Delegation Reflect Church-led Pressure" http://www.ucanews.com/story-archive/?post_name=/1994/09/02/changes-in-cairodelegation-reflect-churchled-pressure\&post_id=45892

Youngblood, Robert L. 1987. "The Corazon Aquino 'Miracle' and the Philippine Churches." Asian Survey 27 (12): 1240-1255.

Youngbood, Robert L. 1998. "President Ramos, the Church, and Population Policy in the Philippines.” Asian Affairs: An American Review 25 (1): 3-19.

\section{Notes}

1 This paper focuses only on reform through policymaking while some may be interested in other forms of reform in general under the Benigno Aquino administration. It also categorizes the policy under the umbrella of social policy following a custom of study on social welfare regimes (cf. Haggard and Kaufman 2008). The actual framing of the policy by the policymakers is more diverse as discussed in sections two and three.

${ }^{2}$ Sidel argues that reform coalitions played a pivotal role in the Sin Tax Reform and the electoral reform in the ARMM (Sidel 2014). The writer appreciates Professor Teresa Encarnacion Tadem of the University of the Philippines for informing him of the work by Sidel. 3 "K-12" stands for Kindergarten to Grade 12-year basic education.

${ }^{4}$ Landmark Legislation, Official Gazette of the Republic of the Philippines. 


\begin{tabular}{|c|l|}
\hline 1 & The Sin Tax Reform Act \\
\hline 2 & The Enhanced Basic Education Act \\
\hline 3 & The Responsible Parenthood and Reproductive Health Act \\
\hline 4 & The Anti-Enforced or Involuntary Disappearance Act \\
\hline 5 & The Human Rights Victims Reparation and Recognition Act \\
\hline 6 & The Expanded Anti-Trafficking in Persons Act of 2012 \\
\hline 7 & The Domestic Workers Act \\
\hline 8 & The AFP Modernization Act \\
\hline 9 & The National Health Insurance Act \\
\hline 10 & The National Electrification Administration Reform Act \\
\hline
\end{tabular}

(http://www.gov.ph/aquino-administration/landmark-legislation/ accessed on April 22, 2015)

${ }^{5}$ After the passage of the RH law, the Supreme Court struck down eight provisions. The writer focuses on the process making the law, because he is interested in the emergence of the policy coalitions, which itself is an intellectual puzzle considering existing literature on Philippine politics.

6 They covered the time period before the inauguration of the Benigno Aquino administration.

7 This paper focuses on the role of ambitious politicians whose actions are essential in the long process of policymaking regardless of their motivation because of two reasons. First, this paper aims at revealing the entire process of policymaking in which ambitious politicians are one of the essential players. Second, the writer believes that it is worth featuring the positive roles of the politicians, which are often forgotten in the literature highlighting oligarchy. It might be a coming agenda to identify the objectives of these politicians in a future study where the researcher should shift its focus from the policymaking to broader political actions by the politicians.

8 The metaphor of porous state comes from the idea of a porous region by Katzenstein (2005).

9 Bautista aptly mentions that there are varieties of position within the Catholic Church (Bautista 2010).

10 According to a survey by the Philippine government, the population growth rates in the 1990s and 2000s were 2.34\% and 1.90\% respectively (Philippine Statistical Authority 2010).

11 She told this writer that that the Catholic Church was the most powerful political player in the country in the context of the ICPD POA in 1997 but that she is not sure today. (personal correspondence, June 11, 2016)

12 http://www.plcpd.com/ accessed on Feb. 2, 2015.

13 http://www.forum4fp.org/ accessed on Nov. 10, 2015.

${ }^{14}$ The following indicator reveals problems in students' performance in mathematics, science and Englisn from 2004 to 2010. 
Performance indicator, achievement rate at secondary school (public school), unit \%

\begin{tabular}{|l|c|c|c|c|c|c|c|}
\hline & $\mathbf{2 0 0 4}$ & $\mathbf{2 0 0 5}$ & $\mathbf{2 0 0 6}$ & $\mathbf{2 0 0 7}$ & $\mathbf{2 0 0 8}$ & $\mathbf{2 0 0 9}$ & $\mathbf{2 0 1 0}$ \\
\hline Mathematics & $50.70 \%$ & $47.82 \%$ & $39.05 \%$ & $42.85 \%$ & $38.03 \%$ & $39.64 \%$ & $42.00 \%$ \\
\hline Science & $39.49 \%$ & $37.98 \%$ & $41.99 \%$ & $46.71 \%$ & $42.11 \%$ & $43.80 \%$ & $39.35 \%$ \\
\hline English & $51.33 \%$ & $47.73 \%$ & $51.78 \%$ & $53.46 \%$ & $52.90 \%$ & $46.95 \%$ & $46.45 \%$ \\
\hline
\end{tabular}

Source: Department of Education factsheet Nov 16, 2011,

(https://web.archive.org/web/20120505102607/http://www.deped.gov.ph/facts andfigures/default.a sp accessed on Nov. 8, 2015).

15 In 2005, the possible electoral fraud during the 2004 election came under the spot light, which resulted in resignation of high rank officials including education secretary Butch Abad. Some of the cabinet members who resigned at that time were appointed department secretaries under the Benigno Aquino administration in 2010.

16 Philippine Business of Education, Board of Trustees (http://www.pbed.ph/organization, accessed on April 22, 2015).

17 The Liberal Party worked for the presidency of Roxas until the time when Roxas withdrew his candidacy and decided to run for the vice presidency with Aquino in 2009. After losing the 2010 election, he was appointed the Secretary of Transportation and Communications (2011-2012) and the Secretary of Interior and Local Government (2012-2015).

18 The Philippine government has three education agencies: the Department of Education for basic education, the Commission on Higher Education for higher education, and the Technical Education and Skills Development Authority for vocational education.

19 The Communist Party of the Philippines as well as its militant organ, the New People's Army, were established in 1968 and 1969 respectively (Rocamora 1994). 